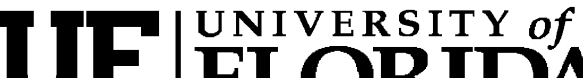 FLORIDA \\ IFAS Extension
}

\section{Improving the Value of Cull Cows by Feeding Prior to Slaughter ${ }^{1}$}

Jeffrey N. Carter and D. Dwain Johnson²

Generally, dollars are left on the table when it comes to marketing cull cows. On average, cull cows can produce ten to twenty percent of the total revenue in a beef cow-calf enterprise. Increasing the value of cull cows by approximately thirty-three percent can improve overall ranch revenue by almost six percent (Example 1). As little as a ten percent increase in net income from the sales of cull cows would nearly double the overall ranch profit margin.

Feeding cows culled from the breeding herd, whether beef or dairy, prior to slaughter is a common practice in many areas of the country; however, it has not been a widely accepted practice in Florida. Because of the availability of many by-product feedstuffs that are economical and accessible in Florida, feeding cull cows is a viable way to add value to an animal that otherwise has only salvage value. Improvements in amount and quality of meat from fed cows has been observed and documented in literature.

Cows with a higher body condition score, and thus weight, optimize economic returns by having both a higher carcass value and a higher live value. Research has shown that cows on full feed for 28 to
56 days had higher carcass weights, which is logical, but also that those increases were due to an increase in carcass lean as well as carcass fat. Although feeding cull cows may not alleviate all issues detailed in the recent National Market Cow and Bull Quality Audit, it does take action on the issues of improving carcass weight, muscling, and fat color.

Finally, and perhaps more relevant, research conducted in Florida in 1991 found that feeding cull cows increased carcass weight, marbling score, and USDA quality grade, as well as 9-10-11 rib section lipid concentration compared with non-fed cows slaughtered at the beginning of the experiment. These researchers also caution, as do we, that the expected profitability of any feeding program must be measured carefully against current market conditions including cattle prices, transportation costs, and the cost of gain. Of course, feeding cows is not free. The numbers in the example above represent revenue increases only - expenses will also increase. However, given the proper economic conditions, a profit may be realized.

Especially relevant to Florida beef cattle production, two experiments were conducted that

1. This document is AN169, one of a series of the Animal Science Department, Florida Cooperative Extension Service, Institute of Food and Agricultural Sciences, University of Florida. Original publication date August 21, 2007. Visit the EDIS Web Site at http://edis.ifas.ufl.edu.

2. Carter, J.N., Assistant Professor of Animal Science, North Florida Research and Education Center Marianna, and Johnson, D., Professor, Department of Animal Sciences, Cooperative Extension Service, Institute of Food and Agricultural Sciences, University of Florida, Gainesville, 32611.

The Institute of Food and Agricultural Sciences (IFAS) is an Equal Opportunity Institution authorized to provide research, educational information and other services only to individuals and institutions that function with non-discrimination with respect to race, creed, color, religion, age, disability, sex, sexual orientation, marital status, national origin, political opinions or affiliations. U.S. Department of Agriculture, Cooperative Extension Service, University of Florida, IFAS, Florida A. \& M. University Cooperative Extension Program, and Boards of County Commissioners Cooperating. Larry Arrington, Dean 
involved feeding cull cows from the same herd in south Florida. The first in 2005 (Year 1) and the second in 2006 (Year 2). In both years, cows were similar in genetics and age. The textured and mixed diet offered in both years was fed ad libitum in self feeders and was composed primarily of the following ingredients: soybean hulls, citrus pulp, cracked corn, wheat middlings, cottonseed hulls, cottonseed meal, molasses, tallow, and urea. The diet contained approximately $87.6 \%$ dry matter, $14 \%$ crude protein (DM basis), and 79.5\% TDN. As a standard practice, an ionophore (Rumensin ${ }^{\circledR}$ [monensin sodium; 80mg/lb]; Elanco Animal Health, Greenfield, IN) was added to help improve feed conversion efficiency. All cows were dewormed on arrival at a feedlot located near Gainesville with a generic ivermectin at label rates. In Year 1, one-half of the cows received a growth-promoting implant (Revelor ${ }^{\circledR}$-IS [80 mg trenbolone acetate plus $16 \mathrm{mg}$ estradiol]; Intervet, Millsboro, DE) on arrival. Carcasses were harvested in both years at a commercial beef processing in central Florida.

\section{Results}

Year 1. As received, the cows (mostly Brangus cross; $n=92$ ) were uniformly thin (BCS $=4.2 \pm 0.3$ ). Individual cow weights (BW) were obtained on $\mathrm{d} 0$, 56 , and 90 . The average cow body weight (BW) on d56 was nearly identical to BW at the end of the feeding period, d90. From this we concluded that long feeding periods or days on feed (DOF) were not necessary under these conditions and were actually costly since cows continued to consume feed from d56 to d90, and gained almost no additional weight. Over the feeding period ( $\mathrm{DOF}=90)$, implanted cows gained more total weight $(259.7 \mathrm{lb}$ vs $230.5 \mathrm{lb} ; P=$ $0.12)$ and ADG was increased ADG (2.9 lb/d vs 2.6 $\mathrm{lb} / \mathrm{d} ; P=0.12$ ) compared with cows that were not implanted.

In a quasi-serial slaughter procedure, we observed that carcass value (Table 1) was increased by $\$ 249$ when cows were fed for 90d compared with selling them thin on $\mathrm{d} 0$. On average, the cost of feeding (feed-only costs) was approximately $\$ 230$ per head. The net result was a difference of $\$ 19$ per head ((\$722.8 [value of fed cows] - \$230 [feed costs only]) - $\$ 473.8$ [value of non-fed cows]), thus showing an economic advantage for feeding these cows.
Year 2. On arrival, the crossbred cows (Beefmaster- and Brangus-cross; $\mathrm{n}=95$ ) were uniformly thin $(\mathrm{BCS}=3.6 \pm 0.4)$. Based on the conclusion reached in Year 1 regarding DOF, this study was designed to feed cows for no more than 50 days. The ending BW for fed cows averaged $1068 \mathrm{lb}$ $( \pm 125)$. Fed cows gained an average of $115 \mathrm{lb}$ during the 48-day feeding period ( $\mathrm{ADG}=2.4 \mathrm{lb}$ per day $)$.

In the same slaughter procedure as in Year 1, carcass values (Table 2) differed by $\$ 151$ per head (harvested $\mathrm{d} 0=\$ 531$; harvested $\mathrm{d} 48=\$ 682$ ).

Although some costs of feeding had increased from the previous year, especially fuel and thus delivery, we assumed the same feeding costs as in Year $1-$ approximately $\$ 2.55 \cdot \mathrm{hd}^{-1} \cdot \mathrm{d}^{-1}$. Since DOF were decreased, feed costs amounted to only $\$ 122.40$ per head. Therefore, the net result of feeding these cows for $0 \mathrm{~d}$ compared with $48 \mathrm{~d}$ was $\$ 28.60$ per head ((\$682 [value of fed cows] - \$122.40 [feed costs]) $\$ 531$ [value of non-fed cows]).

\section{Conclusions}

These data indicate a monetary benefit from feeding cull cows a concentrate diet for approximately 50 to 90 days. The true optimal and maximum days on feed with regard to profitability may vary within that time frame, and will likely depend on current conditions of commodity feed prices and cattle prices alike. At minimum, cows should be implanted with an appropriate growth-promoting implant to maximize feed energy intake and promote optimum feed conversion. A complete and well-balanced diet should be provided and should include an ionophore to improve feed conversion, as well.

Florida beef cattle producers are fortunate to have access to both a variety of commodity feedstuffs and a centrally located slaughter (processing) facility that specializes in cow harvest. The combination of these factors presents a unique opportunity to improve the overall ranch profit margin.

\section{References}

Apple, J.K. 1999. Influence of body condition score on live and carcass value of cull beef cows. J. Anim. Sci. 77:2610-2620. 
Brown, W.F., and D.D. Johnson. 1991. Effects

of energy and protein supplementation of ammoniated tropical grass hay on the growth and carcass characteristics of cull cows. J. Anim. Sci. 69:348-357.

Cranwell, C.D., J.A. Unruh, J.R. Brethour, D.D. Simms, and R.E. Campbell. 1996. Influence of steroid implants and concentrate feeding on performance and carcass composition of cull beef cows. J. Anim. Sci. 74:1770-1776.

Roeber, D.L., P.D. Mies, C.D. Smith, K.E. Belk, T.G. Field, J.D. Tatum, J.A. Scanga, and G.C. Smith. 2001. National Market Cow and Bull Beef Quality Audit-1999: A survey of producer-related defects in market cows and bulls. J.Anim. Sci. 79:658-665.

Sawyer, J.E., C.P. Mathis, and B. Davis. 2004. Effects of strategy and age on live animal performance, carcass characteristics, and economics of short-term feeding programs for culled beef cows. J. Anim. Sci. 82:3646-3653.

Example 1. Contribution of cull cows to ranch revenue

\begin{tabular}{|c|c|c|c|c|c|}
\hline & No. & BW, Ib & $\$ / l b$ & Revenue (\$) & Total (\$) \\
\hline Herd size, cows & 100 & & & & \\
\hline Calf crop \% & 90 & & & & \\
\hline Calves to sell & 90 & 500 & $\$ 1.00$ & $\$ 45,000$ & \\
\hline \multicolumn{6}{|l|}{ Option A: } \\
\hline Open cows to sell & 10 & 950 & $\$ 0.50$ & $\$ 4,750$ & \\
\hline Culled cows & 10 & 950 & $\$ 0.50$ & $\$ 4,750$ & $\$ 54,500$ \\
\hline \multicolumn{6}{|c|}{ Open and culled cows have contributed $17.4 \%$ of the total ranch revenue. } \\
\hline \multicolumn{6}{|l|}{ Option B: } \\
\hline Open cows to sell & 10 & 1150 & $\$ 0.55$ & $\$ 6,325$ & \\
\hline Culled cows to sell & 10 & 1150 & $\$ 0.55$ & $\$ 6,325$ & $\$ 57,650$ \\
\hline
\end{tabular}


Table 1. Animal performance and carcass characteristics by slaughter date: Year 1

\begin{tabular}{|c|c|c|c|c|}
\hline \multirow[b]{2}{*}{ Item } & \multicolumn{2}{|c|}{ Slaughter Date } & \multirow[b]{2}{*}{ Difference } & \multirow[b]{2}{*}{ SEM } \\
\hline & $\mathrm{DOF}^{1}=0$ & $\mathrm{DOF}^{1}=90$ & & \\
\hline Age, $y r^{2}$ & 11.3 & 11.0 & -0.3 & --- \\
\hline Starting $w t, \mathrm{lb}^{2}$ & 872.6 & 867.9 & -4.6 & --- \\
\hline Ending $\mathrm{wt}, \mathrm{lb}^{2}$ & 872.6 & 1112.7 & 240.1 & --- \\
\hline Starting $B C S^{2}$ & 4.3 & 4.2 & -0.1 & --- \\
\hline Ending $\mathrm{BCS}^{2}$ & 4.3 & 6.0 & 1.7 & --- \\
\hline $\mathrm{HCW}, \mathrm{Ib}^{3}$ & 412.2 & 617.8 & 205.6 & 15.3 \\
\hline Marbling $^{3}$ & $134.9^{4}$ & $348.8^{4}$ & 213.9 & 13.0 \\
\hline Rib-eye area, sq. in. ${ }^{3}$ & 7.2 & 11.1 & 3.9 & 0.3 \\
\hline Carcass value, $\$ / \mathrm{hd}^{3}$ & 473.8 & 722.8 & 249.0 & 17.9 \\
\hline $\begin{array}{l}{ }^{1} \text { DOF=Days on feed. } \\
{ }^{2} \text { Simple means. } \\
{ }^{3} \text { LS means. } \\
{ }^{4} 100=\text { Practically dev }\end{array}$ & $=$ Traces & $\mathrm{t} ; 400=s$ & & \\
\hline
\end{tabular}


Table 2. Animal performance and carcass characteristics by slaughter date: Year 2

\begin{tabular}{|c|c|c|c|c|}
\hline \multirow[b]{2}{*}{ Item } & \multicolumn{2}{|c|}{ Slaughter Date } & \multirow[b]{2}{*}{ Difference } & \multirow[b]{2}{*}{ SEM } \\
\hline & $\mathrm{DOF}^{1}=0$ & $\mathrm{DOF}^{1}=48$ & & \\
\hline Age, $\mathrm{yr}^{2}$ & 9.6 & 10.3 & 0.7 & --- \\
\hline Starting $\mathrm{wt}, \mathrm{lb}^{2}$ & 909.5 & 952.7 & 43.2 & --- \\
\hline Ending $w t, \mathrm{lb}^{2}$ & 909.5 & 1068.0 & 158.5 & --- \\
\hline Starting BCS ${ }^{2}$ & 3.4 & 3.6 & 0.2 & --- \\
\hline Ending $\mathrm{BCS}^{2}$ & 3.4 & 6.0 & 2.6 & --- \\
\hline $\mathrm{HCW}, \mathrm{Ib}^{3}$ & 453.8 & 583.1 & 129.3 & 14.1 \\
\hline Marbling $^{3}$ & $210.0^{4}$ & $245.4^{4}$ & 35.4 & 15.0 \\
\hline Rib-eye area, sq. in. ${ }^{3}$ & 10.6 & 10.6 & --. & 0.3 \\
\hline Carcass value, $\$ / \mathrm{hd}^{3}$ & 530.9 & 682.2 & 151.30 & 16.4 \\
\hline $\begin{array}{l}{ }^{1} \text { DOF=Days on feed. } \\
{ }^{2} \text { Simple means. } \\
{ }^{3} \text { LS means. } \\
{ }^{4} 100=\text { Practically de }\end{array}$ & $=$ Traces & ht $; 400=$ & & \\
\hline
\end{tabular}

